\title{
Termosa I. \\ DEVELOPMENT OF PROPOSALS FOR IMPROVING THE FUNCTIONING OF A FAMILY FARM IN A HETEROGENEOUS BUSINESS ENVIRONMENT
}

The research object is the process of creating a family milk farm and its activity efficiency. One of most important requirements as to family milk farm functioning is a possibility to provide high-quality milk production that its functioning efficiency and recoupment of investments for its creation depend on.

A place of family farms as small economic subjects is determined on an example of the total entrepreneurial environment of Ukraine. The scheme of the organizational-economic functioning of family farms, created on the base of rural house economies, is proposed. The dynamics of milk and milk products production and also the dynamics of prices for milk of different sort are determined. Based on conducted studies, the expedience for creating additional production capacities in the field of milk production for industrial processing is substantiated. Actual requirements as to milk quality regulation are studied.

At the research there are used means of system modeling for calculating the efficiency of family milk farm functioning. There are determined Quality parameters, influencing the economic efficiency of milk production at a family farm. They include: real fat share and real protein share in milk. For realizing the calculation of the parameters for the effective milk-good production by a family milk farm, there is proposed an economic-mathematical model of its creation by two variants: minimal and optimal. Due to this model, it is possible to calculate a minimal and maximal sum of investments, and also a period of their recoupment.

Comparing with analogous well-known methods, the proposed approaches allow to determine production parameters of a family farm, to determine a sum of investments, to calculate a period of their recoupment.

Keywords: entrepreneurial environment, family farm, family milk farm, agricultural production, agrarian economic sector.

\section{Introduction}

Under conditions of the globalized and highly integrated market environment, one of main tasks for its participants is to provide the sustainable development of rural economy and formation of the competitive agrarian production. Introduction of sustainable development mechanisms provides the increase of entrepreneurial activity and formation of multi-order economy, which component is small and middle agribusiness, able to raise the total socio-economic stability of rural territories and to support their innovative development. The support of creation and development of small forms of economy at rural territories in totality allows to solve a large number of socio-economic tasks. Such tasks are to decrease social stain, to increase population's employment, to achieve an optimal structure of the agroindustrial complex (AIC), to saturate the market with food goods, to refill budgets of local communities with finances and so on. For that it is extremely important to activate the development of enterprises and to form principles for supporting strivings and efforts of entrepreneurial groups for providing own economic growth and one of a correspondent rural territory. And also to provide formation of a local community of agricultural producers, striving for recognition among the population of own rural territory. We propose to concentrate on the support of the private family milk farms' development. Such economic form in the developed countries is considered almost most important, because it allows many population layers to realize entrepreneurial activity and to raise their general socio-economic life level, stimulates the development of service spheres of agribusiness, processing, cooperation.

Works of a significant number of scientists are devoted to the question of studying the efficiency of farm economies' functioning in the agrarian sector. Thus, the authors of work [1] study the efficiency of farm economy management depending on selected assessment criteria. The study is based on an interrogation of managers of farm economies in Great Britain. The scientists paid essential attention to questions of farm management style, staff management methods, business-aims and tasks, personal qualities of a farmer - as an owner of an enterprise, and also determine how these questions influence the economic efficiency of farm economies' functioning. But the authors didn't pay attention to questions of milk raw materials' quality 
and its influence on the economic efficiency of farm economies' functioning. Parameters of studied farms, number of animals, kept at them, their technological maintenance are absent.

Work [2] analyzes an interconnection between time, spent by a milk farm manager, and key directions of management and financial parameters of a milk farm. There were analyzed management key directions. They include milk quality and quantity, comfort and feeding of animals, decrease of metabolic disorders rate, offspring and its keeping, financial reporting, plant cultivation and human resource management. The scientist proved that the time, spent for managerial decisions as to milk quality and quantity maintenance, decrease of metabolic disorders rate and financial management by a manager negatively influences the pure income of a farm. At that decisions, aimed at the increase of cows' comfort, their feeding, increase of offspring care quality and also human resource management positively influence it. The results of this study are aimed at helping milk farm leaders to structure the direction of managerial actions and at increasing financial indices. But the author doesn't study the amount of financial investment for realization of proposed solutions, doesn't determine the period of their recoupment.

The authors of work [3] study the efficiency of a program of diffusion of field knowledge among farmers. The obtained data at the level of farm economies are used by the scientists for estimating the economic influence of discussion groups of milk products on the economic efficiency of a farm. The estimation is based on raising the profit of own economies by participants of the discussion groups, estimated by the regression model. The scientists focus attention on individual characteristics of a farmer that may influence the profitability of a farm. The study noted that the economic return from the membership in the discussion group is positive. But the work doesn't note parameters of the studied farm economies, number of cows, kept on them and also the level of mechanization and technical equipment.

Thus, the research object was chosen as the process of milk farm creation and its activity efficiency. It seems expedient to base the studies on determining the effectiveness of family milk farm functioning depending on milk raw material quality. For getting the maximal price for milk products, it is necessary to provide the milk production process according to the state standard of a correspondent country for milk and milk products, observing all sanitary-hygienic norms. All this needs additional capital investments in building and equipment. Without using modern approaches of economic-mathematic modeling, it is rather difficult to determine optimal parameters of a family milk farm.

Main attention in a parametric mathematical-economic model must be paid to determining the economic effectiveness of milk production by a family milk farm depending on quality class, fat and protein content and also recoupment period of investment for providing the production process. The outlined problem is not enough considered in modern scientific literature that it its turn testifies to the necessity for its further research.

The aim of the work is to determine conditions of economic expedience of creation and functioning of family farms as small economic subjects on an example of the total entrepreneurial environment of Ukraine.

\section{Research methodology}

General scientific and special research methods were used at the work:

- the method of theoretical generalization, grouping and comparison - for studying the organizational-economic characteristics of family farms, created based on rural house economies. There is a transfer to the characteristic of the motivational model of family farm creation;

- functional-cost analysis - includes studying of the total technological system of milk production and estimation of factors, influencing the economic efficiency of this type of products;

- system analysis for estimating the interaction of the family farm creation process with using system modeling, taking into account main factors, influencing its economic efficiency and also helping to determine the recoupment period of investments in this project;

- the method of logic generalization - for theoretical substantiation of the importance of set problems and specification of key notions of the study.

\section{Research results and their discussion}

Under conditions of globalization and integration of world economies in the united economic space, the process of transfer to the new economic order essentially accelerated. But just for today the functioning entrepreneurial environment in the agrarian sector contains the essential number of unregulated problems, braking processes of its development and functioning effectiveness of its main agents - entrepreneurs [4].

At this condition of the entrepreneurial environment, the main way for getting income for most rural people is agricultural production activity. At that the able-bodied rural population has a choice - to work as employees or to develop an own entrepreneurial business.

For today certain positive changes in these questions appear. The Law of Ukraine «On introducing changes to the Law of Ukraine «On farm economy» as to stimulation of creation and activity of family farm economies» was adopted [5]. According to it, family farms gain rights of juridical person by their state registration or without creating a juridical person, but by registering a leader of a family farm economy as a physical person-entrepreneur. According to this law, an economy, organized without creating a juridical person, is organized by a physical person-entrepreneur independently or together with family members, based on an agreement. It is concluded by all members of one family in written form and must be notarially certified. A leader of such farm economy is a family member, registered as a physical person-entrepreneur. Thus, the initial object of a family farm is a rural house economy.

It must be also noted, that for today the state support in correspondence with the Law of Ukraine «On state support of agriculture of Ukraine» is real and actual for such forms of economy.

Based on studied scientific works and normative-legal acts on questions of the essence and aspects of family farms activity [4-6], their main features are determined. In first, a family farm is a social formation (initial cell of society), where a family is an owner, based on own house economies. In second, it may be in a form of juridical or physical person. In third, it embodies economic 
values and aims and gets good products and entrepreneurial income at the expanse of own labor at a garden and/or share plot.

Family farm economies may be involved in different schemes of agricultural production, rural, eco- and ethno-tourism, and other services. They may specialize in the field of agricultural good production in animal products, for example, milk, different types of meat, honey, breeding and realization of lake fish or in the plant field, such as cultivation of niche varieties - sweet potato, asparagus, color cabbage and broccoli, seeds of pumpkin and other products and also ones of gardening and berry cultivation (Fig. 1).

It must be also noted, that at creating a family farm economy or family farm the main motivation factor is always to increase financial incomes for a family by realizing entrepreneurial activity in rural places. But for the possibility of functioning at the rather competitive market of agricultural products and raw materials, it is expedient for a family farm economy to study a possibility of integration to more competitive united structures, such as agricultural servicing cooperatives and also holding or cluster structures. Thus, integration of a family farm to, for example, a servicing cooperative gives it a possibility to get services in forage stocking, protection means supply, veterinary, creation of milk stocking centers and so on. It totally results in decreasing a total sum of outcomes and raises the farm functioning efficiency. It is rather problematically for family house economies to provide the high competitiveness level of own products and strong market positions independently without enough state financial support

Studying the sphere of activity of a family farm, such as production of milk as a raw material for industrial processing, we must stop on actual production volumes of this type of goods in Ukraine and its dynamics (Table 1).

It must be accented, that actual production indices of milk and milk products for 2017-2019 in dynamics have a tendency to decrease. According to rational norms of annual consumption of milk and milk products by one person at the level of $380 \mathrm{~kg}$, only $203 \mathrm{~kg}$ were consumed in 2019 that is by $47 \%$ less than the determined needs. The enough supply of milk goods in the retail network is a result of increased prices for it and doesn't correspond to the actual consumption demand.

We also can talk that for today there is a rather favorable price situation. Existent purchasing prices for milk of the higher sort grew essentially and favored the increase of the branch profitability level (Fig. 2). At further preservation of this situation, the rather fast recoupment of investments and, correspondingly, the branch attractiveness growth will take place.

Studying the dynamics of prices for milk of different sorts, we can surely talk about the price growth for milk of the higher sort, and the price for products of a lower quality, including ones from population's economies, is not so attractive.

So, starting creation of a family farm, an entrepreneur must distinctly understand that the most important production parameters are milk quality that influences farm functioning efficiency parameters.

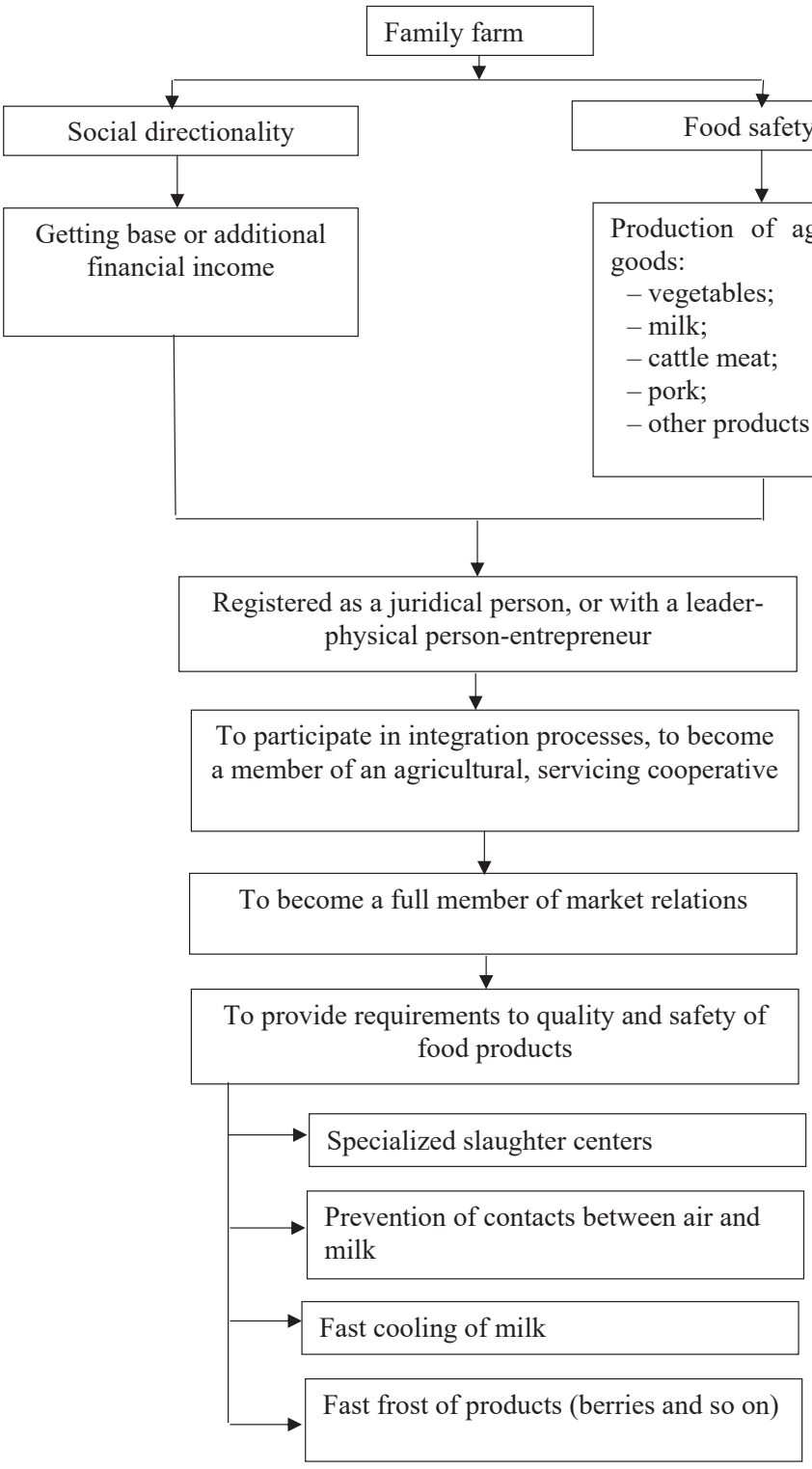

Fig. 1. Perspectives of a milk farm at the market of agricultural producers

Table 1

Actual indices of milk and milk products production for 2017-2019, thousands of tons

\begin{tabular}{|c|c|c|c|c|}
\hline Parameters & $\begin{array}{c}2017 \\
\text { (actual) }\end{array}$ & $\begin{array}{l}2018 \\
\text { (actual) }\end{array}$ & $\begin{array}{l}2019 \\
\text { (actual) }\end{array}$ & $\begin{array}{c}\text { In } \\
\text { dynamics }\end{array}$ \\
\hline Demand for products & 10459 & 9616 & 10022 & -437 \\
\hline Internal market - totally & 9618 & 8864 & 9481 & -137 \\
\hline $\begin{array}{l}\text { including: } \\
\text { Consumption fund }\end{array}$ & 8518 & 7864 & 8531 & 13 \\
\hline Other consumption & 1100 & 1000 & 950 & -150 \\
\hline External market (export*) & 841 & 752 & 541 & -300 \\
\hline Supply of products & 10459 & 9616 & 10022 & -437 \\
\hline Internal market - totally & 10329 & 9457 & 9687 & -642 \\
\hline $\begin{array}{l}\text { including: } \\
\text { Own production }\end{array}$ & 10329 & 9457 & 9687 & -642 \\
\hline External market (import*) & 130 & 159 & 355 & 225 \\
\hline $\begin{array}{l}\text { Consumption for a person, } \\
\text { рег уеаг }\end{array}$ & 188.5 & 189 & 202.9 & 14.4 \\
\hline
\end{tabular}

Note: based on data [7]; * - without taking into account the temporally occupied territory of the Autonomous Republic Crimea and Sevastopol city 


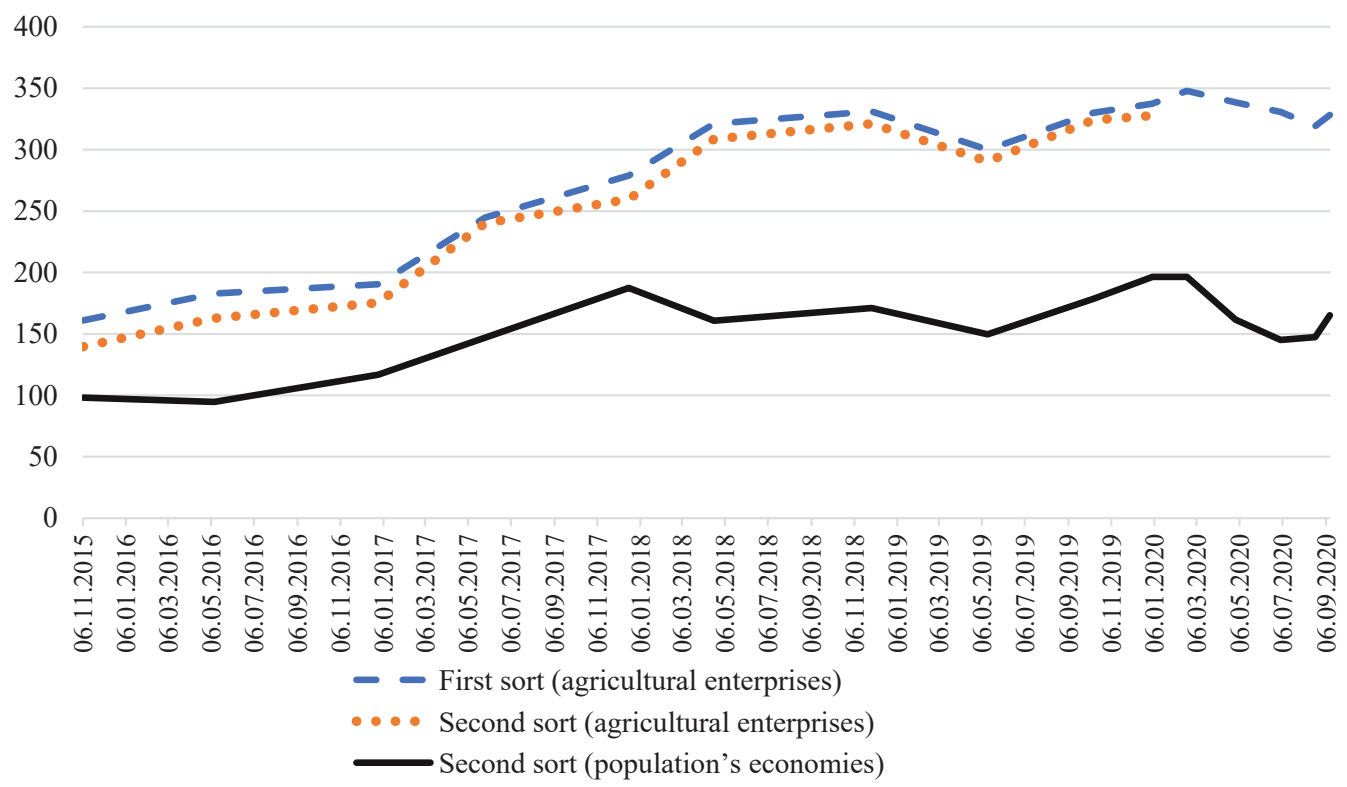

Fig. 2. Dynamics of prices for milk of different quality for 2015-2020 dol/ton (based on data [8])

Studying questions of normative-legal regulation of requirements to milk quality, it must be noted, that according to the actual quality standard SSU 3662-97 «Non-skimmed cow milk. Requirements at purchase» whole milk is divided in the extra, higher, first and second sorts depending on a level of bacterial contamination and content of somatic cells [9].

The order of milk sort formation depending on a level of bacterial contamination and content of somatic cells is given in Table 2 .

The base price of milk of different quality classes forms according to Branch recommendations BRU 46.018-2002 «On order of payment for milk depending on sort, fat and protein content by SSU». Thus, the base contractual price for milk is considered as a purchasing price of $1 \mathrm{t}$ of milk of the first sort at base mass shares of fat and protein without an added value tax and dotation. The regulation of the Cabinet of Ministries of Ukraine from 25.10.2002 No. 1589 «On approval of base norms of a mass share of fat and protein in cow non-skimmed milk» [11] established the base norms for cow milk: fat - $3.4 \%$, protein $-3.0 \%$. At that the state stimulates producers to increase production of high-quality raw materials for further processing by giving correspondent additional payments. Thus, for milk of the higher sort there is an extra charge as $15 \%$ of the base price. And on the contrary, for second sort milk production there is a discount as $10 \%$ of the purchase price for the first sort milk, taking into account the actual mass share of fat and protein.

Sort formation of milk according to existent requirements

\begin{tabular}{|c|c|c|c|c|c|}
\hline Quality sort & Acidity, ${ }^{\circ} \mathrm{T}$ & $\begin{array}{c}\text { Density, } \mathrm{kg} / \mathrm{m}^{3} \\
\text { at temperature } \\
+20{ }^{\circ} \mathrm{C}\end{array}$ & $\begin{array}{l}\text { Cleanness Group } \\
\text { by the reference } \\
\text { standard }\end{array}$ & $\begin{array}{c}\text { Bacterial } \\
\text { semination, } \\
\text { thousand/cm }\end{array}$ & $\begin{array}{c}\text { Somatic } \\
\text { cells, } \\
1000 / \mathrm{cm}^{3}\end{array}$ \\
\hline Extra & from 16 to 17 & 1028 & I & 100 & 400 \\
\hline Higher & from 16 to 17 & 1028 & I & 300 & 400 \\
\hline First sort & from 16 to 18 & 1027 & I & 500 & 600 \\
\hline Second sort & from 16 to 18 & 1027 & II & 3000 & 800 \\
\hline
\end{tabular}

Note: based on data [10] protein: of milk (Table 3).

So, the price for milk is calculated by the following formula, taking into account the actual content of fat and

$$
P m=(F a / 3.4 \%) \cdot 0.4+(P a / 3.0 \%) \cdot 0.6) \cdot P b,
$$

where $P m$ - milk price; $F a$ - actual index of the fat mass share in a job lot, \%; $P a$ - actual index of the protein mass share in a job lot, \%; $P b$ - base price according to the sort.

Having actual quality indices of milk and base price, we can compare the production efficiency of different sorts

Studying the effectiveness of milk production depending on the quality indices, we can state the fact that the total sum of income from production totally depends on its quality. Thus, at mass shares of fat and protein in milk at the level of $4 \%$ and $3.6 \%$, respectively, its price may be 0.38 dol for $1 \mathrm{~kg}$ of products, at mass shares of fat as $3.4 \%$ and protein as $3 \%$ the price is $0.16 \mathrm{dol}$. The price is also influenced by indices of acidity, bacterial semination, number of somatic cells (Table 2). At that the calculating sum of income per day is $94.6 \mathrm{dol}$ at the high milk quality and $29.6 \mathrm{dol}$ at the low one.

Obviously, for getting milk of the high quality, it is necessary to observe all sanitary-hygienic norms. That is why for providing such production capacities, founders of a family farm must invest costs, used for building or modernization of an accommodation for keeping 10-12 cows, for purchasing technical devices and equipment for milking

Table 2 and storing milk and so on. The calculating list of the sum of investment costs is presented in Table 4 .

The calculating sum of costs for building a family farm needs at least $44865 \mathrm{dol}$ without taking into account costs for buying pregnant cows. This sum includes costs for materials and building of an accommodation of a farm itself, necessary technical equipment of it, and also ones for storing milk and other costs. At that near $3994.8 \mathrm{dol}$ is necessary for current outcomes annually. 
Production efficiency of milk depending on quality indices

\begin{tabular}{|c|c|c|c|c|c|}
\hline No. & Рагаmeter & \multicolumn{2}{|l|}{ High quality } & \multicolumn{2}{|l|}{ Low quality } \\
\hline 1 & Base price, dol $/ \mathrm{kg}$ & Extra (agricultural enterprises) & 0.3 & Second sort (population's economy) & 0.16 \\
\hline 2 & Fat, \% & 4 & 0.15 & 3.4 & 0.07 \\
\hline- & - & - & $(4 / 3.4 \cdot 0.4) \cdot 0.3$ & - & $(3.4 / 3.4 \cdot 0.4) \cdot 0.16$ \\
\hline 3 & Protein, \% & 3.6 & 0.23 & 3 & 0.10 \\
\hline- & - & - & $(3.6 / 3 \cdot 0.6) \cdot 0.3$ & - & $(3 / 3 \cdot 0,6) \cdot 0,16$ \\
\hline 4 & Total price (fat+protein), dol/kg & \multicolumn{2}{|l|}{0.38} & \multicolumn{2}{|l|}{0.16} \\
\hline 5 & Total amount of received milk, 1 & \multicolumn{2}{|l|}{250} & \multicolumn{2}{|l|}{180} \\
\hline 5.1 & Number of cows, heads & 10 & & 10 & \\
\hline 5.2 & Milk per cow, l & 25 & & 18 & \\
\hline 6 & Total sum of income, dol & \multicolumn{2}{|l|}{94.6} & \multicolumn{2}{|l|}{29.6} \\
\hline
\end{tabular}

Note: based on data [10]

\section{Table 4}

Investment costs for building a cowshed for 10 stall-places, dol

\begin{tabular}{|c|l|c|c|}
\hline No. & \multicolumn{1}{|c|}{ Investment directions } & $\begin{array}{c}\text { Minimal } \\
\text { variant }\end{array}$ & $\begin{array}{c}\text { Optimal } \\
\text { variant }\end{array}$ \\
\hline 1 & Material and work (building) & 27825.0 & 37000.0 \\
\hline 2 & Cost of technical equipment & 5100.0 & 12657.1 \\
\hline 3 & Costs of equipment for milk storage & 2940.0 & 4450.0 \\
\hline 4 & Other costs & 9000.0 & 10000.0 \\
\hline 5 & Total costs & 44865.0 & 64107.1 \\
\hline 6 & Total costs for 1 animal & 4486.5 & 6410.7 \\
\hline
\end{tabular}

Note: based on data [10]

This sum of costs (fully or partially), necessary for starting a farm for 10 stall-places, may be obtained from state or commercial credit institutions, from participation in State or regional financing programs or other financing variants.

Studying expenditures for milk production, it must be noted, that one of main expenditures of a farm is forage provision (Fig. 3). At the low variant the percent of expenditures for forge is near $69 \%$, at the high variant - $49 \%$.

The expedience of a project of creating a family farm is determined based on plan economic indices, main of which are profit volume, profitability level and recoupment term.

Taking into account different prices of milk realization, depending on quality characteristics (high milk quality $-0.38 \mathrm{dol} / \mathrm{kg}$, low milk quality $-0.16 \mathrm{dol} / \mathrm{kg}$ ), the calculating income (receipts) from realization may vary within 9171 dol - 29350 dol per year. At that the calculating profit by annual activity results may vary within 5179.8 dol - 23255.2 dol. The production profitability is minimally $130 \%$. At keeping the minimal profitability level, capital investments will be recouped during 9 years, at the maximal profitability - the recoupment will be at the level of 3 years (Table 5).

It must be noted, that a project of creating a family milk farm is one of optimal variants of investment of small costs in the milk branch. But all depends on a possibility to create such production conditions, at which the quality milk is maximal.

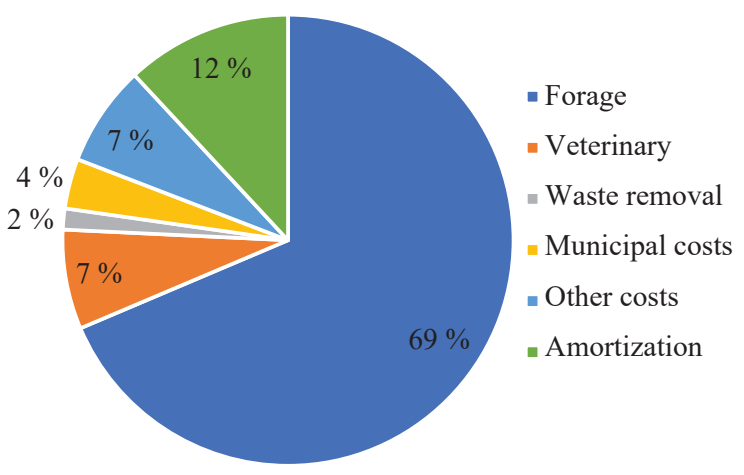

$a$

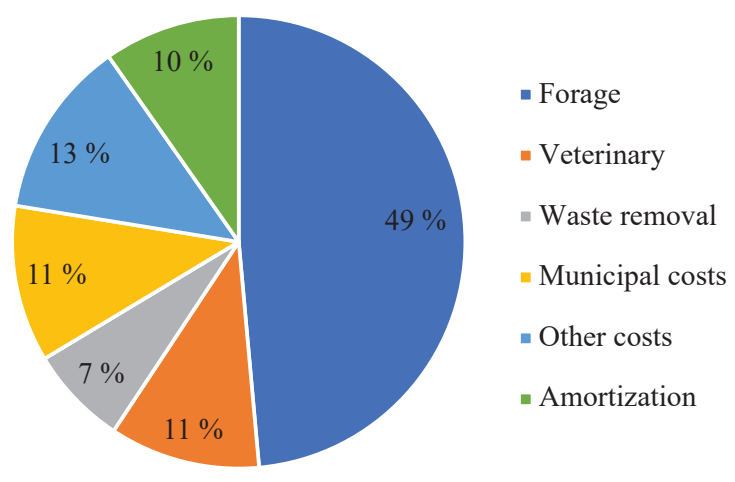

Fig. 3. Structure of costs for milk production, \%: $a$ - low result; $b$ - high result

Table 5

The recoupment of investments for building a cowshed of 10 stall-places

\begin{tabular}{|l|c|c|}
\hline \multicolumn{1}{|c|}{ Parameter } & $\begin{array}{c}\text { Minimal } \\
\text { variant }\end{array}$ & $\begin{array}{c}\text { Optimal } \\
\text { variant }\end{array}$ \\
\hline Investments (farm for 10 cows), dol & 44865.0 & 64107.0 \\
\hline Profit from realization, dol & 5179.8 & 23255.2 \\
\hline Investments recoupment, years & 9 & 3 \\
\hline
\end{tabular}

\section{Conclusions}

It has been determined, that small entrepreneurial structures have the essential influence on the development of both the agroindustrial complex and rural territories, 
so, on the socio-economic status of the rural population. There have been offered promising directions of family farm activity at the Ukrainian market of agricultural producers. The expedience of integration processes of a family farm into different organization-legal forms of integrated structures has been substantiated. The author definition of the notion of family farm, in which the economic subject is a family, and activity motivation is getting additional financial income, has been proposed.

The first-turn factors, influencing the economic efficiency of family milk farm activity have been determined. Production results of milk by a family farm depending on quality class, fat and protein content have been proposed, and the recoupment period of investments for providing the production process, obtained by the parametric economicmathematical model, has been determined.

It is determined, that depending on quality characteristics of obtained milk, the calculating income from realization may vary within 9 171-29 350 dol per year. The calculating profit by annual activity results may vary within 5 179.8-23 255.2 dol. The production profitability is minimally $130 \%$. At keeping the minimal profitability level, capital investments will be recouped during 9 years, at the maximal profitability - the recoupment will be near 3 years.

\section{References}

1. O'Leary, N. W., Bennett, R. M., Tranter, R. B., Jones, P. J. (2018). The extent that certain dairy farmer attitudes and behaviors are associated with farm business profitability. Journal of Dairy Science, 101 (12), 11275-11284. doi: http://doi.org/ 10.3168/jds.2017-14307
2. Braun, C. M. (2012). An Analysis of How Dairy Farmers Divide Their Time among Twelve Key Management Areas and Farm Profitability. Available at: https://hdl.handle.net/1813/29537

3. Läpple, D., Hennessy, T., Newman, C. (2013). Quantifying the Economic Return to Participatory Extension Programmes in Ireland: an Endogenous Switching Regression Analysis. Journal of Agricultural Economics, 64 (2), 467-482. doi: http://doi.org/ 10.1111/1477-9552.12000

4. Malik, M. Y. (2016). Pidpryiemnytstvo i rozvytok silskykh terytorii. Ekonomika APK, 6, 97-103.

5. Pro vnesennia zmin do Zakonu Ukrainy «Pro fermerske hospodarstvo» shchodo stymuliuvannia stvorennia ta diialnosti simeinykh fermerskykh hospodarstv (2016). Zakon Ukrainy No. 1067-VIII. 31.03.2016. Vidomosti Verkhovnoi Rady (VVR), 21, 406.

6. Malik, M. Y., Zaiats, V. M. (2013). Teoretychni zasady ta napriamy transformatsii osobystykh selianskykh hospodarstv. Ekonomika APK, 5, 87-95.

7. Popyt i propozytsiia na molochnu produktsiiu. Available at: http:// milkua.info/uk/post/section/supply-and-demand

8. Dynamika tsin na molochnu produktsiiu. Available at: http:// milkua.info/uk/ukr-milk-prices

9. Poiasniuvalna zapyska do proektu pershoi redaktsii DSTU 3662:2015 «Moloko-syrovyna koroviache. Tekhnichni umovy» (2017). Available at: http://iprkyiv.com/index.php/87-poyasnyuvalna-zapyska-doproektu-pershoi-redaktsii-dstu-36622015-moloko-syrovyna-koroviache-tekhnichni-umovy

10. Kremers, Ya. Kh., Teres, V. M., Maksymov, M. H. (2017). Posibnyk z molochnoho fermerstva. Kyiv: KOMPRYNT, 120.

11. Pro skhvalennia bazysnykh norm masovoi chastky zhyru $i$ bilka u molotsi koroviachomu nezbyranomu (2002). Postanova Kabinetu Ministriv Ukrainy No. 1589. 25.10.2002. Available at: https:// zakon.rada.gov.ua/laws/show/1589-2002-п\#Text

Termosa Iryna, PhD, Vice-Rector for Scientific and Pedagogical Work, Oleksandr Dovzhenko Hlukhiv National Pedagogical University, Sumy Region, Ukraine, e-mail: bojarinova.ira13@gmail.com, ORCID: http:// orcid.org/0000-0002-4996-173X 